\title{
Speciation and dynamics of dissolved inorganic nitrogen export in the Danshui River, Taiwan
}

\author{
T.-Y. Lee ${ }^{1}$, Y.-T. Shih ${ }^{2}$, J.-C. Huang ${ }^{2}$, S.-J. Kao ${ }^{3}$, F.-K. Shiah ${ }^{4}$, and K.-K. Liu ${ }^{5}$ \\ ${ }^{1}$ Department of Geography, National Taiwan Normal University, Taipei, Taiwan \\ ${ }^{2}$ Department of Geography, National Taiwan University, Taipei, Taiwan \\ ${ }^{3}$ State Key Laboratory of Marine Environmental Science, Xiamen University, Xiamen, China \\ ${ }^{4}$ Research Center of Environmental Changes, Academia Sinica, Taipei, Taiwan \\ ${ }^{5}$ Institute of Hydrological and Oceanic Sciences, National Central University, Taoyuan, Taiwan
}

Correspondence to: J.-C. Huang (riverhuang@ntu.edu.tw)

Received: 14 January 2014 - Published in Biogeosciences Discuss.: 12 February 2014

Revised: 20 August 2014 - Accepted: 3 September 2014 - Published: 2 October 2014

\begin{abstract}
Human-induced excess nitrogen outflowing from land through rivers to oceans has resulted in serious impacts on terrestrial and coastal ecosystems. Oceania, which occupies $<2.5 \%$ of the global land surface, delivers $12 \%$ of the freshwater and dissolved materials to the ocean on a global scale. However, there are few empirical data sets on riverine dissolved inorganic nitrogen (DIN) fluxes in the region, and their dynamics are poorly understood. In this study, a river monitoring network covering different types of land uses and population densities was implemented to investigate the mechanism of DIN export. The results show that DIN concentration/yield varied from $\sim 20 \mu \mathrm{M} / \sim 300 \mathrm{~kg}$ $\mathrm{N} \mathrm{km}^{-2} \mathrm{yr}^{-1}$ to $\sim 378 \mu \mathrm{M} / \sim 10000 \mathrm{~kg}-\mathrm{N} \mathrm{km}^{-2} \mathrm{yr}^{-1}$ from the relatively pristine headwaters to the populous estuary. Agriculture and population density control DIN export in less densely populated regions and urban areas, respectively, and runoff controls DIN at the watershed scale. Compared to documented estimates from global models, the observed DIN export from the Danshui River is 2.3 times larger, which results from the region-specific response of DIN yield to dense population and abundant runoff. The dominating DIN species change gradually from $\mathrm{NO}_{3}^{-}$in the headwaters $(\sim 97 \%)$ to $\mathrm{NH}_{4}^{+}$in the estuary $(\sim 60 \%)$ following the urbanization gradient. The prominent existence of $\mathrm{NH}_{4}^{+}$is probably the result of the anaerobic water body and short residence time, unlike in large river basins. Given the analogous watershed characteristics of the Danshui River to the rivers in Oceania, our study could serve as a first example to examine riverine DIN fluxes in Oceania.
\end{abstract}

\section{Introduction}

Nitrogen, a vital element in living organisms, plays a critical role in controlling primary production in the biosphere. Along with fossil fuel combustion to meet the food demand of mankind, human activities have greatly increased the amount of actively cycling nitrogen during the past decades (Galloway and Cowling, 2002; Galloway et al., 2004; Boyer et al., 2006; Seitzinger et al., 2010). Added anthropogenic reactive nitrogen enters drainage basins through atmospheric deposition, the direct application of nitrogenous fertilizer, land use changes and sewage (Dumont et al., 2005). Consequently, excess nitrogen discharged from land to oceans has resulted in seasonal coastal hypoxia, harmful algal blooms, and decreased fishery production in ecosystems (Howarth et al., 1996; Rabalais, 1996; Jickells, 1998; Boesch, 2002; Turner et al., 2003; Galloway et al., 2004; Duan et al., 2007; Conley et al., 2009; Billen and Garnier, 2007; Diaz and Rosenberg, 2008). However, most current knowledge about dissolved inorganic nitrogen $\left(\mathrm{DIN}=\mathrm{NH}_{4}^{+}+\mathrm{NO}_{3}^{-}+\mathrm{NO}_{2}^{-}\right)$export has derived from larger river systems in developed countries of Europe and North America; much less attention has been paid to developing countries in Oceania in the tropical western Pacific Ocean. Oceania is surrounded by stratified oligotrophic water with limited bio-available nutrients, particularly nitrogenous nutrients (Jiao et al., 2007; Martha and Kristen, 2012).

Oceania, composed of numerous high-standing islands with mountainous watersheds, experiences active tectonics and extremely high soil erosion rates (Milliman and Syvitski, 
1992; Kao and Milliman, 2008). Annually, $\sim 27$ tropical cyclones (typhoons) pass through this region, bringing torrential rainfall which triggers flushing floods (Webster et al., 2005; Tu and Chou, 2013). Collectively, Oceania discharges $6.8 \mathrm{Gt}$ of sediment annually to the ocean $(\sim 40 \%$ of the global total), even though these islands account for less than $2.5 \%$ of the global land area (Milliman and Farnsworth, 2013). In addition, Oceania rivers deliver $\sim 12 \%$ of global fresh water and dissolved solids to the ocean (Seitzinger et al., 2005; Milliman and Farnsworth, 2013), underscoring the potential importance of DIN discharge. The DIN export from Oceania was predicted to increase by more than $10 \%$ by 2030 compared to the 1995 level due to urbanization, sanitation, the development of sewer systems, and lagging wastewater treatment (Seitzinger et al., 2002; Bouwman et al., 2005). Although global models have demonstrated Oceania to be a hot spot of global DIN export, no intensive network of DIN monitoring exists or has ever been implemented or documented for Oceania rivers. A previous study that monitored the DIN in headwater catchments of Taiwan determined that global models are likely to underestimate nitrogen yields for rivers in Oceania (Lee et al., 2013). To better project future DIN discharge from global land surfaces, data from subtropical small watersheds are required.

Countries in Oceania including the Philippines, Indonesia and Papua New Guinea are all in a stage of fast development. Taiwan has geographic and climatic features similar to the islands of Oceania, i.e., high precipitation, steep slopes, small basin areas, and frequent flood events (Milliman et al., 1999; Milliman and Farnsworth, 2013). Moreover, the rugged terrain of these islands offers limited space to accommodate towns and agricultural lands; thus, cities are all located at downstream flood plains and tillage is often inevitably located on steep slopes (Huang et al., 2012b). With these hydrological and geomorphological similarities, Taiwanese rivers have long been considered analogous to the rivers of Oceania (Kao and Liu, 2000, 2002; Kao et al., 2005; Lee et al., 2013). Because of their short water residence times in the watershed, high flow velocities and soil erosion rates, we also expect the controlling factors for DIN export, speciation and dynamics over the river continuum to differ from those of large rivers.

Taiwan, a small island, holds 23 million people on an island of $\sim 36000 \mathrm{~km}^{2}$ (i.e. $\sim 638 \mathrm{cap} \mathrm{km}{ }^{-2}$, one of the most densely populated countries in the world). Wastewater disposal from the capital city Taipei in the downstream of the Danshui River along with agricultural activities in the upstream have had a significant biogeochemical influence on the river continuum (Wen et al., 2008). In this paper, we investigated the DIN speciation and fluxes in the Danshui River network, where different types of human alteration increase from upstream to downstream. The observed DIN exports were correlated to runoff, land use and population and further compared with global data sets. The objectives of this study are: (1) to explore the factors governing DIN export and spe-

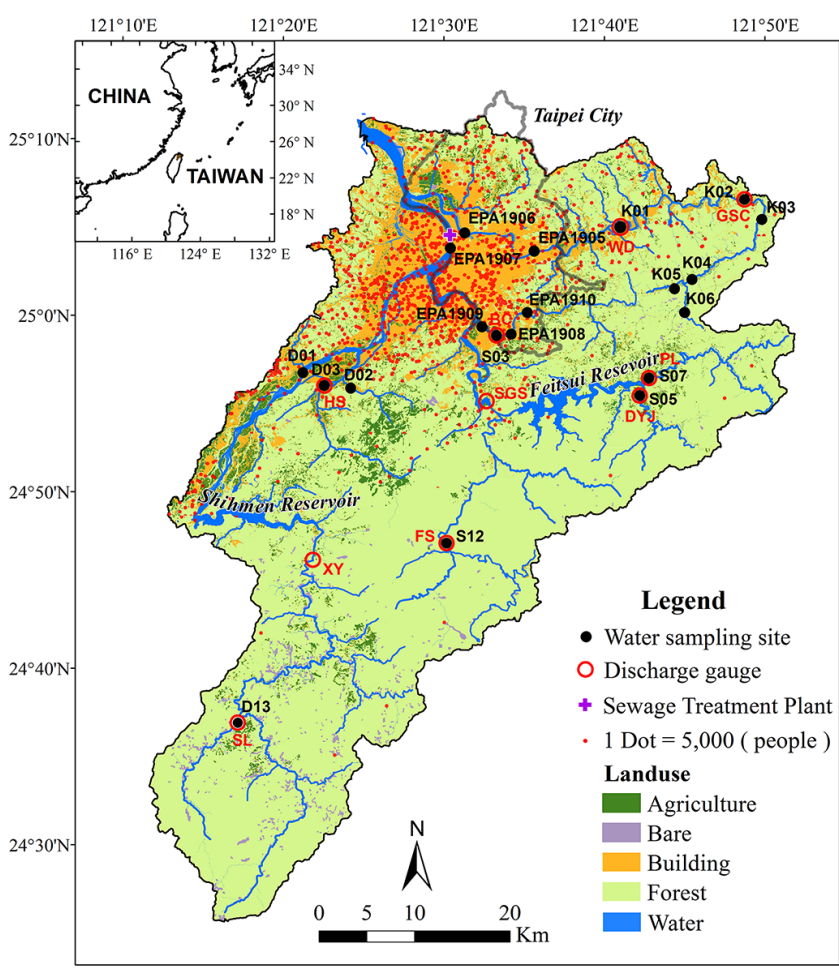

Figure 1. The map of land use and population density distribution in the Danshui River watershed. The land use and population data are sourced from the Ministry of Interior. Locations of water sampling sites (black dots), runoff gauges (red circle), and sewage treatment plants (cross symbol) are marked. The grey curve represents the boundary of Taipei City.

ciation; and (2) to construct a practical equation for DIN discharge in mountainous watersheds. The results may provide a scientific background for stream restoration and nutrient mitigation in Oceania rivers.

\section{Materials and methods}

\subsection{Danshui watershed}

The Danshui River, the third largest river in Taiwan, originates from Mt Pin-Tian (3529 ma.s.l.) and has a drainage area of $2,726 \mathrm{~km}^{2}$ (Fig. 1). It drains through the capital city, Taipei, at the downstream flood plain. Taipei has 5.7 million people living in an area of $376 \mathrm{~km}^{2}$ (i.e. $15200 \mathrm{cap} \mathrm{km}^{-2}$ ). The annual precipitation is approximately 2500-4000 $\mathrm{mm} \mathrm{yr}^{-1}$, and the annual mean temperature is approximately $22^{\circ} \mathrm{C}$. Three major tributaries, the Dahan (D), Singdian (S) and Keelung (K) Rivers, merge to the east of Taipei City (Huang et al., 2012a). Among the three major tributaries, the Dahan River, which drains from south to north, is the longest with a stream length of $135 \mathrm{~km}$. The Shihmen reservoir in the middle of the Dahan River is one of the most important hydrologic constructions for 
Table 1. Watershed characteristics, land use compositions, discharge and rainfall for each sampling site. Sites are arranged in sequence according to their distances to the estuary. Upstream sites (distance to the estuary $>70 \mathrm{~km}$ ) are in bold. The distance is measured from the shoreline. The tidal excursion distance is $\sim 10-20 \mathrm{~km}$ upriver, depending on tidal range and weather conditions. Bare land use usually includes landslide and outcrop.

\begin{tabular}{|c|c|c|c|c|c|c|c|c|c|c|c|c|c|}
\hline \multirow{3}{*}{ Site ID } & \multirow{3}{*}{ Tributary } & \multicolumn{3}{|c|}{ Watershed characteristics } & \multicolumn{5}{|c|}{ Land use Composition } & \multicolumn{4}{|c|}{ Runoff } \\
\hline & & Distance & Area & Population & Building & Agricultural & Forest & Water & Bare & Gauge & Annual & Dry & Wet \\
\hline & & $(\mathrm{km})$ & $\left(\mathrm{km}^{2}\right)$ & $\left(\right.$ cap km ${ }^{-2}$ ) & $(\%)$ & $(\%)$ & $(\%)$ & $(\%)$ & $(\%)$ & & $(\mathrm{mm})$ & $(\mathrm{mm})$ & $(\mathrm{mm})$ \\
\hline D13 & D & 125 & 119 & 16 & 0.2 & 1.4 & 96.7 & 0.7 & 1.0 & SL & 1174 & 320 & 849 \\
\hline D01 & $\mathrm{D}$ & 40 & 857 & 158 & 3.6 & 4.8 & 87.7 & 2.9 & 1.0 & $\mathrm{XY}$ & 1391 & 381 & 1005 \\
\hline D03 & D & 39 & 126 & 489 & 4.0 & 13.1 & 81.9 & 0.9 & 0.1 & HS & 1410 & 517 & 893 \\
\hline D02 & D & 37 & 54 & 488 & 5.0 & 23.1 & 70.8 & 0.7 & 0.5 & HS & 1539 & 673 & 854 \\
\hline EPA1907 & $\mathrm{D}$ & 16 & 2101 & 1492 & 8.9 & 5.6 & 82.3 & 2.7 & 0.5 & XY, SGS & 2420 & 820 & 1594 \\
\hline K06 & $\mathbf{K}$ & 93 & 7 & 81 & 1.5 & 1.3 & 96.4 & 0.6 & 0.2 & GSC & 3255 & 1851 & 1408 \\
\hline K05 & $\mathbf{K}$ & 90 & 9 & 81 & 4.6 & 2.3 & 91.9 & 1.0 & 0.2 & GSC & 3150 & 1791 & 1362 \\
\hline K04 & $\mathbf{K}$ & 87 & 37 & 81 & 3.1 & 2.2 & 93.4 & 1.1 & 0.2 & GSC & 3345 & 1902 & 1447 \\
\hline K03 & $\mathbf{K}$ & 74 & 85 & 157 & 3.2 & 1.7 & 93.6 & 1.4 & 0.1 & GSC & 3308 & 1881 & 1431 \\
\hline K02 & $\mathrm{K}$ & 62 & 124 & 476 & 6.9 & 1.9 & 89.5 & 1.7 & 0.1 & GSC & 3285 & 1868 & 1421 \\
\hline K01 & $\mathrm{K}$ & 47 & 203 & 1054 & 11.4 & 2.6 & 84.0 & 1.9 & 0.0 & WD & 3551 & 1722 & 1828 \\
\hline EPA1905 & $\mathrm{K}$ & 32 & 328 & 1930 & 15.4 & 3.5 & 79.2 & 1.9 & 0.0 & WD & 3551 & 1722 & 1828 \\
\hline EPA1906 & K & 16 & 361 & 2618 & 19.9 & 3.2 & 74.6 & 2.1 & 0.0 & WD & 3551 & 1722 & 1828 \\
\hline S12 & $\mathbf{S}$ & 72 & 163 & 15 & 0.3 & 0.1 & 98.4 & 0.5 & 0.6 & FS & 3209 & 1171 & 2030 \\
\hline S07 & $\mathbf{S}$ & 72 & 111 & 54 & 2.0 & 4.8 & 91.8 & 1.3 & 0.1 & PL & 2754 & 1273 & 1947 \\
\hline S05 & $\mathbf{S}$ & 71 & 79 & 38 & 0.8 & 2.1 & 96.0 & 0.9 & 0.1 & DYJ & 1890 & 823 & 1413 \\
\hline EPA1910 & $\mathrm{S}$ & 40 & 91 & 645 & 8.6 & 7.5 & 82.8 & 1.1 & 0.0 & $\mathrm{BC}$ & 2294 & 710 & 1577 \\
\hline EPA1908 & S & 36 & 106 & 1737 & 13.0 & 7.7 & 78.1 & 1.1 & 0.0 & $\mathrm{BC}$ & 2289 & 708 & 1573 \\
\hline S03 & $\mathrm{S}$ & 34 & 111 & 1969 & 13.9 & 8.5 & 76.5 & 1.2 & 0.0 & $\mathrm{BC}$ & 2184 & 676 & 1501 \\
\hline EPA1909 & $\mathrm{S}$ & 31 & 115 & 2061 & 16.0 & 8.2 & 74.5 & 1.2 & 0.0 & $\mathrm{BC}$ & 2120 & 656 & 1457 \\
\hline Danshui River & & 2697 & 2187 & 14.1 & 5.4 & 77.2 & 2.8 & 0.4 & & 2360 & 869 & 1486 & \\
\hline
\end{tabular}

irrigation, hydroelectric power, water supply and flood prevention in Taiwan. It serves a $365 \mathrm{~km}^{2}$ irrigation area and 1.8 million people. The Feitsui reservoir is another reservoir that is located in the middle reach of the Singdian River; it was designed to provide the drinking water supply for Taipei city, and the upstream of this reservoir is thus legally preserved. For the entire Danshui watershed, forest is the dominant land use, although its proportion gradually decreases from $\sim 97 \%$ in the upstream to $\sim 75 \%$ in the downstream due to the expansion of human-associated land uses (Table 1). Correspondingly, population density increases from $\sim 10 \mathrm{cap} \mathrm{km}^{-2}$ at the headwaters to $\sim 2000 \mathrm{cap} \mathrm{km}^{-2}$ in the downstream and reaches a maximum in the district of Taipei City.

\subsection{Discharge, land use and population data}

In Taiwan, the Water Resource Agency (WRA) is responsible for monitoring river discharge. River discharge is estimated by substituting consecutive water levels into the individual rating curve, which is calibrated by field measurements every year. There are 10 flow gauges in the Danshui watershed. For the sampling sites without flow gauges, the daily discharges can be derived from the area proportion of the adjacent gauges (Kao et al., 2004; Lee et al., 2013). In the years 2002-2005, the runoff for the Danshui River was

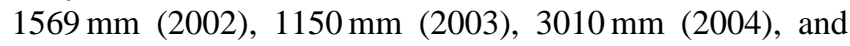

$3223 \mathrm{~mm}$ (2005), exhibiting a significant fluctuation $(\sim 50$ $130 \%$ ) compared to the long-term mean of $\sim 2500 \mathrm{~mm}$. Land use data were retrieved from aerial photos taken during 1996-1998 by the National Land Surveying and Mapping Centre. The Taiwanese government carried out a census approximately every 10 years. The Ministry of the Interior (http://www.ris.gov.tw/) provides the township-based population data. We applied the data from the year 2000 to the watershed-based density for further analyses.

\subsection{Water sampling and chemistry}

Stream water samples were collected from the three major tributaries at 14 sites in the middle and upper reaches from 2002-2004 (Fig. 1). The fundamental watershed characteristics (flow distance, watershed area and population density), land use compositions and runoff depth for each sampling site are shown in Table 1. Data from six more sites in the downstream maintained by EPA (Environment Protection Administration) from 2002-2005 were taken to complete the full basin scale DIN variability. Eight of the 20 stations were equipped with flow gauges for flux calculations. Note that the discharges at the other 12 sites were estimated using the adjacent flow gauges. The sampling sites were classified into upstream and downstream subsets at distance of $70 \mathrm{~km}$ from the river mouth (a proximate boundary of rural and city area where that marks the onset of significant human-alteration in 
Table 2. Observed dissolved oxygen (DO), DIN concentrations, compositions of DIN species and their corresponding sample numbers and sampling periods. Upstream sites are in bold.

\begin{tabular}{|c|c|c|c|c|c|c|c|c|c|c|c|c|}
\hline \multirow{3}{*}{ Site ID } & \multirow{3}{*}{$\begin{array}{l}\text { Sample } \\
\text { number }\end{array}$} & \multirow{3}{*}{$\begin{array}{c}\text { Sampling } \\
\text { period }\end{array}$} & \multicolumn{6}{|c|}{ DIN concentration $(\mu \mathrm{M})$} & \multicolumn{3}{|c|}{ DIN species (\%) } & \multirow[t]{3}{*}{$\mathrm{DO}(\mu \mathrm{M})$} \\
\hline & & & \multicolumn{2}{|c|}{ Annual } & \multicolumn{2}{|c|}{ Dry season } & \multicolumn{2}{|c|}{ Wet season } & $\mathrm{NO}_{3}$ & $\mathrm{NO}_{2}$ & $\mathrm{NH}_{4}$ & \\
\hline & & & mean & std & mean & std & mean & std & & & & \\
\hline D13 & 198 & 24 Feb 2002-15 Apr 2004 & 21.1 & 9.5 & 17.6 & 6.7 & 24.5 & 10.6 & 94 & 1 & 6 & 187 \\
\hline D01 & 21 & 24 Feb 2002-31 Mar 2004 & 68.9 & 44.8 & 76.0 & 54.3 & 63.1 & 34.1 & 75 & 5 & 21 & 168 \\
\hline D03 & 21 & 24 Feb 2002-31 Mar 2004 & 162.4 & 75.9 & 160.0 & 73.8 & 164.3 & 77.6 & 38 & 5 & 56 & 117 \\
\hline D02 & 21 & 24 Feb 2002-31 Mar 2004 & 120.3 & 73.1 & 133.5 & 94.2 & 108.3 & 42.9 & 71 & 4 & 25 & 187 \\
\hline EPA1907 & 45 & 15 Jan 2002-13 Dec 2005 & 377.8 & 239.2 & 433.8 & 251.0 & 324.3 & 214.2 & 38 & 1 & 61 & 34 \\
\hline K06 & 203 & 29 Mar 2002-30 Apr 2004 & 22.1 & 6.2 & 21.1 & 5.6 & 23.3 & 6.6 & 96 & $\mathbf{0}$ & 3 & 249 \\
\hline K05 & 203 & 29 Mar 2002-30 Apr 2004 & 23.2 & 11.1 & 24.0 & 10.4 & 22.2 & 11.8 & 88 & 2 & 10 & 274 \\
\hline K04 & 8 & 28 Feb 2002-10 Feb 2004 & 20.1 & 13.8 & 16.0 & 8.2 & 26.2 & 17.8 & 90 & 2 & 8 & 246 \\
\hline K03 & 8 & 28 Feb 2002-10 Feb 2004 & 29.8 & 11.5 & 28.7 & 6.6 & 31.5 & 16.1 & 92 & 3 & 7 & 243 \\
\hline K02 & 8 & 28 Feb 2002-10 Feb 2004 & 96.3 & 20.0 & 89.1 & 14.3 & 103.4 & 22.3 & 64 & 9 & 37 & 201 \\
\hline K01 & 21 & 28 Feb 2002-31 Mar 2004 & 223.8 & 113.3 & 188.3 & 113.1 & 256.0 & 103.4 & 44 & 7 & 49 & 160 \\
\hline EPA1905 & 45 & 14 Jan 2002-12 Dec 2005 & 283.8 & 173.8 & 273.7 & 185.3 & 293.5 & 161.6 & 30 & 4 & 67 & 65 \\
\hline EPA1906 & 45 & 14 Jan 2002-12 Dec 2005 & 272.2 & 143.9 & 262.5 & 155.6 & 281.4 & 131.1 & 28 & 2 & 70 & 30 \\
\hline S12 & 8 & 27 Feb 2002-12 Feb 2004 & 19.7 & 6.0 & 17.2 & 6.3 & 23.3 & 3.0 & 77 & 2 & 22 & 255 \\
\hline S07 & 389 & 28 Feb 2002-29 Dec 2005 & 54.1 & 17.3 & 50.2 & 13.9 & 57.8 & 19.3 & 90 & 1 & 9 & 210 \\
\hline S05 & 389 & 28 Feb 2002-29 Dec 2005 & 34.8 & 11.8 & 32.9 & 9.0 & 36.6 & 13.7 & 97 & $\mathbf{0}$ & 3 & 228 \\
\hline EPA1910 & 45 & 16 Jan 2002-12/13 Dec 2005 & 168.6 & 111.6 & 158.7 & 74.6 & 178.1 & 137.3 & 52 & 5 & 42 & 107 \\
\hline EPA1908 & 45 & 16 Jan 2002-13 Dec 2005 & 199.4 & 94.0 & 205.2 & 82.3 & 193.9 & 103.7 & 46 & 5 & 49 & 115 \\
\hline S03 & 52 & 5 Jan 2002-31 Mar 2004 & 236.2 & 118.7 & 273.6 & 138.4 & 200.3 & 81.0 & 39 & 8 & 58 & 120 \\
\hline EPA1909 & 45 & 16 Jan 2002-13 Dec 2005 & 342.1 & 213.4 & 358.8 & 211.4 & 326.1 & 214.1 & 43 & 5 & 52 & 89 \\
\hline
\end{tabular}

terms of population density and land use composition). Such spatially intensive monitoring in the river network provides a great opportunity to distinguish the effects of urbanization on DIN flux and speciation. Water samples were collected at different frequencies covering both the dry (November-March) and wet (April-October) seasons. The number of samples taken at each site is shown in Table 2.

Water samples were immediately filtered through GF / F filters $(0.7 \mu \mathrm{m})$ after collection. The filtrates were quickfrozen in liquid nitrogen for water chemistry analyses. Nitrate, nitrite and ammonium content were determined by ion chromatography (IC) using a Dionex ICS-1500 instrument with detection limits of $0.2,0.2$, and $0.4 \mu \mathrm{M}$, respectively. The reported DIN denotes the summation of nitrate, nitrite and ammonium concentrations. Dissolved oxygen (DO) was measured in situ using an HI9828 probe produced by Hanna Instruments with an accuracy of $3 \mu \mathrm{M}$.

\subsection{Flux calculation}

In this study, four commonly used methods - linear interpolation (LI), global mean (GM), flow weighted (FW) and the rating curve (RC) method - were applied to estimate the individual DIN fluxes of the 20 sites. Each of the four methods, which have been widely discussed in previous studies, have specific advantages, although no single method is universally suitable for all watersheds (Ferguson, 1987; Preston et al., 1988; Moatar and Meybeck, 2005; Birgand et al.,
2010). To prevent subjective or arbitrary choices, the four method-derived fluxes at each site were then averaged and normalized by drainage area to represent flux and yield, respectively. Please refer to the Supplementary Information for details.

\section{Results}

\subsection{Spatial distribution of DIN}

The DIN speciations and concentrations for the 20 sampling sites are listed in Table 2. In the Dahan tributary, the annual mean concentration ranges from $21 \mu \mathrm{M}$ in the upstream (D13) to $378 \mu \mathrm{M}$ in the downstream (EPA1907), showing a downstream increasing trend. With only two exceptions (D13 in the upstream and D03 in the downstream), the mean DIN concentrations in the wet season are lower than those in the dry season.

In the Keelung tributary, the annual mean DIN concentration is $\sim 24 \mu \mathrm{M}$ at the upstream sites and increases to above $96 \mu \mathrm{M}$ from K02 toward the downstream. The DIN concentration reaches a maximum of $284 \mu \mathrm{M}$ in EPA1905 and is slightly moderated to $272 \mu \mathrm{M}$ at EPA1906 within the tidal excursion distance. In this tributary, most of the DIN concentrations in wet season are higher than those in the dry season (except at K05).

Unlike the previous two tributaries, the water sampling sites in the Sindian tributary are actually distributed in three 

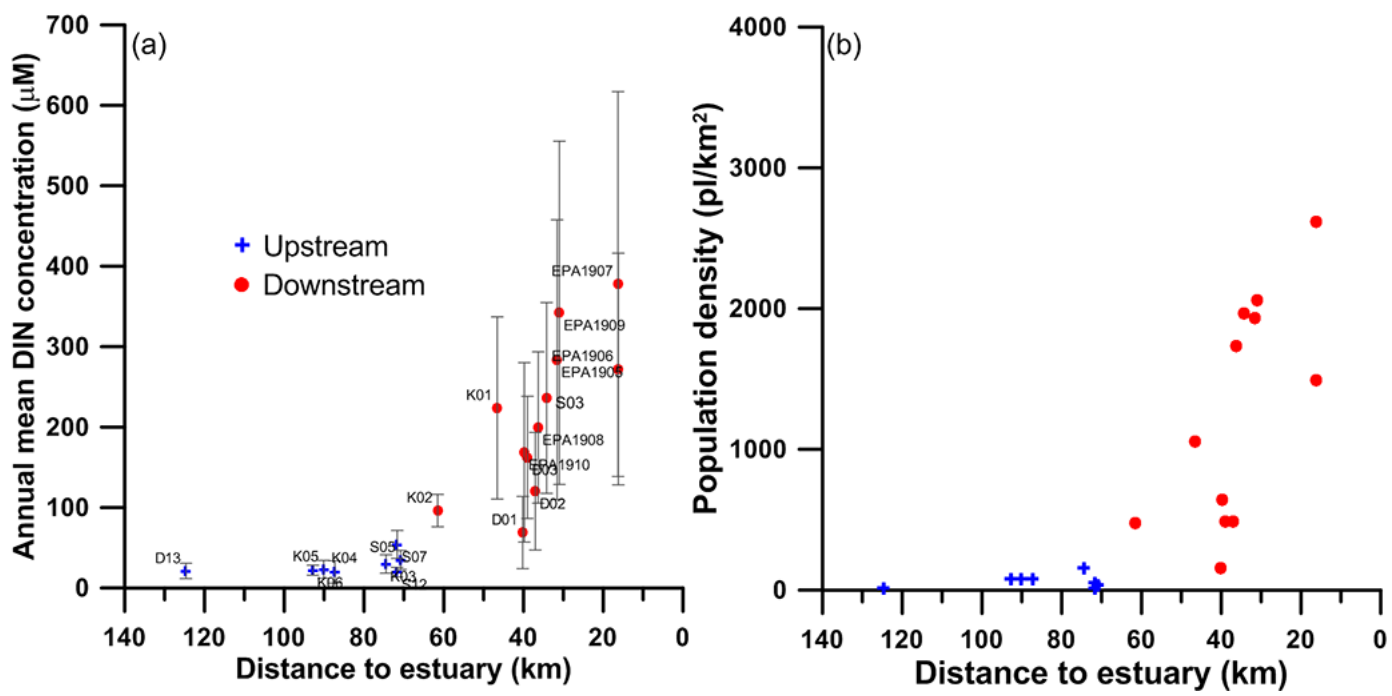

Figure 2. Longitudinal distributions of (a) measured DIN concentration and (b) population density along the Danshui River. Bars in (a) represent the standard deviation of measurements. The blue crosses and red circles indicate the upstream and downstream sites, respectively.

Table 3. The correlation matrix among population density, runoff and land use composition. The Pearson correlation coefficients are shown. The observed DIN concentrations are grouped into two subsets: upstream and downstream data.

\begin{tabular}{lrrrrrrr}
\hline & Pop $\left(\mathrm{cap} \mathrm{km}^{-2}\right)$ & $\mathrm{Q}(\mathrm{mm})$ & Building $(\%)$ & Agri. $(\%)$ & Forest $(\%)$ & Water $(\%)$ & Bare $(\%)$ \\
\hline Pop (cap km ${ }^{-2}$ ) & 1 & -0.30 & $0.97^{*}$ & -0.11 & $-0.70^{*}$ & 0.19 & -0.38 \\
$Q(\mathrm{~mm})$ & & 1 & -0.29 & -0.41 & 0.49 & -0.26 & -0.35 \\
Building (\%) & & & 1 & 0.16 & $-0.80^{*}$ & 0.42 & -0.51 \\
Agricultural (\%) & & & & 1 & $-0.71^{*}$ & -0.16 & -0.03 \\
Natural (\%) & & & & & & -0.28 & 0.33 \\
Water (\%) & & & & & & 1 & 0.10 \\
Bare Land (\%) & & & & & & & 1 \\
Whole data & $0.84^{*}$ & -0.08 & $0.80^{*}$ & 0.26 & $-0.74^{*}$ & 0.48 & -0.31 \\
Upstream & 0.01 & 0.24 & -0.01 & $0.78^{*}$ & -0.43 & 0.48 & -0.42 \\
Downstream & $0.68^{*}$ & -0.18 & $0.59^{*}$ & -0.21 & -0.34 & 0.18 & -0.26 \\
\hline
\end{tabular}

* indicates a significant correlation.

main branches. At S12, the annual mean DIN concentration is $19.7 \mu \mathrm{M}$, which is comparable to the background sites of the Dahan and Keelung Rivers. Although S07 and S05 are closely located in another branch, S07 is located in a town and has a DIN concentration of $54.1 \mu \mathrm{M}$, which is higher than that of S05 $(34.8 \mu \mathrm{M})$. EPA1910, EPA1908, S03 and EPA1909 are located in yet another branch in the urban district and have annual mean DIN concentrations ranging from $169 \mu \mathrm{M}$ to $342 \mu \mathrm{M}$. In terms of the tributaries, the trend in annual mean DIN concentration increases moving downstream. Downstream from EPA1910, the annual mean DIN concentrations in the dry season were higher than those in the wet season.

\subsection{DIN concentrations and watershed characteristics}

The overall longitudinal patterns of DIN concentration and population density are shown in Fig. 2a and b, respectively. Both the DIN concentration and population density show an upward trend and surge simultaneously as the boundary between upstream and downstream is crossed. The annual DIN concentrations are clearly strongly correlated with population density, with a Pearson correlation coefficients $(\rho)$ of 0.84 . Table 3 shows the Pearson correlation coefficients between the observed mean DIN concentrations and the potential controlling factors including population density, runoff and land use composition. For the entire data set, the DIN concentrations are correlated to building proportion $(\rho=0.80)$, which is associated with population density and negatively correlated to forest proportion $(\rho=-0.74)$; owing to the competition between forest and building land 


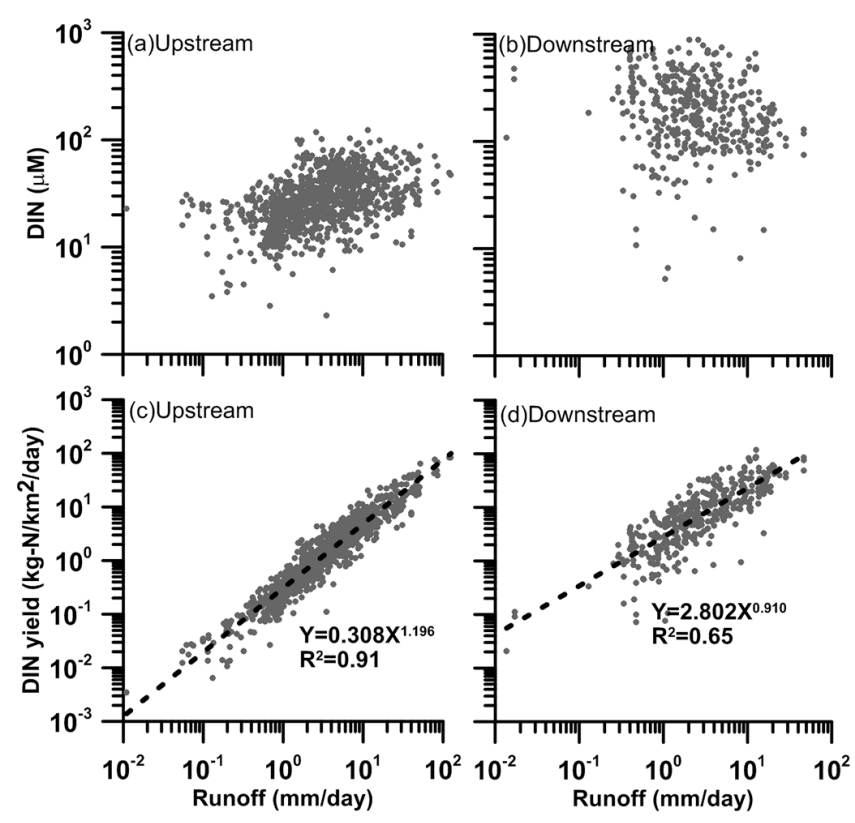

Figure 3. Sampled DIN concentrations and yields plotted against runoff at all upstream $(\mathbf{a}, \mathbf{c})$ and downstream sites $(\mathbf{b}, \mathbf{d})$. The dashed lines in $(\mathbf{c}, \mathbf{d})$ are power regression equations of the samples.

uses, $\rho=-0.80$ ). A closer examination of the upstream and downstream data sets reveals that their controlling factors are different. For the downstream subset, as in the whole data set, DIN concentrations are positively correlated to two population-associated factors: population density $(\rho=0.68)$ and building land use proportion $(\rho=0.59)$. For the upstream subset, however, agricultural land use proportion controls the DIN concentrations with $\rho=0.78$.

\subsection{DIN concentrations/yields and runoff}

Figure 3 shows scatter plots of the DIN concentrations and yields against runoff for the upstream and downstream sites, revealing different influences of runoff on upstream/downstream DIN transport. In the upstream (Fig. 3a), the DIN concentration corresponds to the runoff patterns, indicating a positive concentration-runoff $(\mathrm{C}-\mathrm{Q})$ relationship. A change in runoff of four orders of magnitude accompanies a two-orders of magnitude change in DIN concentration; this results in a strong relationship between DIN yield and runoff with $R^{2}=0.91$ (Fig. 3c). In the downstream, the C-Q plot is relatively scattered (Fig. 3b), yet shows a slightly negative relationship. Nevertheless, runoff still controls the DIN transport, as shown in Fig. 3d.

Figure 4 further shows the scatter plots of DIN concentrations and yields against runoff for selected upstream and downstream sites in the three tributaries. The $\mathrm{C}-\mathrm{Q}$ relationships in the upstream (blue crosses in Fig. 4a-c) and downstream (red circles) sites follow the overall patterns shown in Fig. 3a and $\mathrm{b}$. The strong positive correlations between the observed DIN yields and runoff (Fig. 4d-f) again illustrate that hydrology exerts a strong control on DIN export, particularly for the upstream sites. These relationships can be well depicted by a power function with high coefficients of determination $\left(R^{2}>0.85\right)$ for the upstream sites. For the downstream sites, the relationships are not as strong; however, $R^{2}>0.5$, indicating that runoff is still the dominant influence on DIN export. The cumulative DIN yields for the selected sites are presented in Fig. $4 \mathrm{~g}-1$. The daily yields are calculated based on the power function (shown in Fig. 4d-f) calculated by substituting the 2002-2005 daily runoff values into the formula. Note that the cumulative DIN yields of the upstream sites display a stepwise increasing pattern (Fig. $4 \mathrm{~g}-$ i) due to typhoon-triggered flooding. Such high runoff events contribute a great deal to the annual DIN export. The cumulative DIN yields of the downstream sites (Fig. $4 \mathrm{j}-1$ ) reveal a constant rate, although the rate is $\sim 2 \mathrm{x}$ greater after mid-2004. The effect of high runoff events can also be observed for the downstream sites (Fig. 4j-k) underlying the smooth cumulative curves, which might be obscured by different controlling factors.

\subsection{Spatial distribution of DIN yields}

The mean DIN yields of the 20 sites during 2002-2005 are shown in Table 4. The differences among DIN yields derived from the four methods are small; with the exception of D01 and K02, the coefficients of variation (CV) are less than $30 \%$, demonstrating that method-associated manipulation is limited in our study. In the Dahan tributary, DIN yields range from $322 \mathrm{~kg}-\mathrm{N} \mathrm{km}^{-2} \mathrm{yr}^{-1}$ at D13 to $10094 \mathrm{~kg}$ $\mathrm{N} \mathrm{km}^{-2} \mathrm{yr}^{-1}$ at EPA1907. In the Keelung tributary, DIN

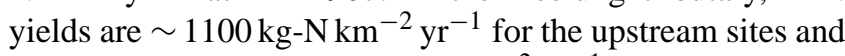
abruptly elevate to $>4291 \mathrm{~kg}-\mathrm{N} \mathrm{km}^{-2} \mathrm{yr}^{-1}$ from K02 toward the downstream, showing an increasing trend toward the estuary (except EPA1906). In the Sindian River, S12 represents a background DIN yield at $734 \mathrm{~kg}-\mathrm{N} \mathrm{km}^{-2} \mathrm{yr}^{-1}$. At S07, a small town in the upstream, a high DIN yield of $2522 \mathrm{~kg}$ $\mathrm{N} \mathrm{km}^{-2} \mathrm{yr}^{-1}$ is observed. For the downstream sites, the DIN

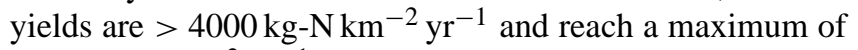
$6510 \mathrm{~kg}-\mathrm{N} \mathrm{km}^{-2} \mathrm{yr}^{-1}$ at EPA1909.

Figure 5 shows the relationships between the annual DIN yields from 2002-2005 at each site and runoff, population density and agricultural proportion. The relationships are individually examined in terms of the Pearson correlation coefficients $(\rho)$ for the upstream and downstream subsets and the whole data set. Fitted lines are drawn only if $\rho$ values are greater than 0.70 . Runoff undoubtedly has a strong influence on DIN yields for the three data sets (Fig. 5a). Population density only exerts control over the whole data set (Fig. 5b). The DIN yields in the upstream are better correlated to the agricultural proportion (Fig. 5c). Although agricultural proportions are higher in the downstream, the population density, which masks the effects of agriculture, overwhelmingly controls the DIN yields. 
Table 4. The DIN yields at each sampling site. Four calculation methods are applied in this study. Upstream sites are coloured in italic.

\begin{tabular}{lrrrrrr}
\hline & \multicolumn{5}{c}{ DIN yield $\left(\mathrm{kg}-N ~ k m^{-2} \mathrm{yr}^{-1}\right)$, globally } \\
\cline { 2 - 7 } Site ID & LI & GM & FW & RC & Mean & CV $(\%)^{*}$ \\
\hline D13 & 319 & 285 & 326 & 357 & 322 & 9.1 \\
D01 & 973 & 1089 & 1129 & 1968 & 1290 & 35.4 \\
D03 & 1743 & 1998 & 1973 & 1525 & 1810 & 12.3 \\
D02 & 1700 & 1897 & 1914 & 1642 & 1788 & 7.7 \\
EPA1907 & 10748 & 11602 & 10027 & 8000 & 10094 & 15.2 \\
\hline K06 & 899 & 811 & 965 & 876 & 888 & 7.1 \\
K05 & 900 & 805 & 996 & 969 & 918 & 9.3 \\
K04 & 810 & 1407 & 1496 & 993 & 1177 & 27.9 \\
K03 & 1106 & 1870 & 1955 & 1232 & 1541 & 28.2 \\
K02 & 3158 & 5653 & 5537 & 2817 & 4291 & 35.3 \\
K01 & 9234 & 8721 & 9040 & 7022 & 8504 & 11.9 \\
EPA1905 & 13516 & 12583 & 9665 & 6815 & 10645 & 28.5 \\
EPA1906 & 11689 & 11329 & 9882 & 6785 & 9921 & 22.5 \\
\hline S12 & 727 & 709 & 715 & 784 & 734 & 4.7 \\
S07 & 2577 & 2452 & 2526 & 2535 & 2522 & 2.1 \\
S05 & 1185 & 1025 & 1125 & 1191 & 1132 & 6.8 \\
EPA1910 & 5919 & 5600 & 4543 & 3266 & 4832 & 24.8 \\
EPA1908 & 4597 & 5082 & 4802 & 3216 & 4424 & 18.8 \\
S03 & 4269 & 4415 & 4499 & 3124 & 4077 & 15.8 \\
EPA1909 & 5949 & 7341 & 7990 & 4759 & 6510 & 22.2 \\
\hline
\end{tabular}

* $\mathrm{CV}$ denotes coefficient of variation.

\subsection{Spatial distribution of DIN composition and dissolved oxygen}

Figure 6 shows the overall longitudinal distributions of DO (Fig. 6a), DIN composition (Fig. 6b-d) and DIN concentration (Fig. 6e-h) along the Danshui River. The DIN compositions evidently change from upstream to downstream, while the DIN concentration increases downstream-ward. In the Dahan tributary, nitrate dominates in the upstream, and ammonium emerges in the downstream (Table 2). Nitrite, only accounting for $<5 \%$ of DIN, plays a minor role in DIN composition. DO concentration remains relatively steady until EPA1907, where it drops to $34 \mu \mathrm{M}$. In the Keelung tributary, nitrate contributes $\sim 94 \%$ of DIN in the upstream reach. In the middle reach of the Keelung River (K02 and K01), the ammonium in the DIN composition increases by an order of magnitude. In the lowest reach (EPA1905 and 1906), ammonium surges to $\sim 68 \%$ of DIN concentration. Nitrate and nitrite contribute $\sim 29 \%$ and $\sim 3 \%$, respectively. DO concentration begins to decrease when the river flows by K03. The DO concentration is $\sim 270 \mu \mathrm{M}$ in the upstream; DO then decreases at a rate of $\sim 3.1 \mu \mathrm{M} \mathrm{km}^{-1}$ to $30 \mu \mathrm{M}$ at EPA1906. Like the Dahan and Keelung rivers, the nitrate proportion of the DIN in the Sindian River is less in the downstream than in the upstream, with ammonium becoming the leading species. The DO concentrations also reveal a decreasing trend toward the estuary, with minor variations.
Generally, DO concentrations are $>200 \mu \mathrm{M}$ in the upstream and $<120 \mu \mathrm{M}$ in the downstream. The $\rho$ values between DO and nitrate/ammonium proportion are $0.89 /-0.90$, respectively (not shown). DIN appears in the form of nitrate in higher DO conditions; in contrast, ammonium appears in lower DO conditions. The relative proportion of nitrite reaches its maximum in the middle reach, where DO concentration remains at a moderate level. Nitrite, which is hardly detected due to its low stability in water, shows little correlation with dissolved oxygen $(\rho=-0.27)$.

\section{Discussion}

\subsection{Controlling factors on DIN export}

Because upstream catchments are critical to understand source inputs to downstream river systems, our data set demonstrates the spatial transport behaviour of DIN and the urbanization effect. As mentioned earlier, nitrate concentrations at the upstream sites (population density $<150$ cap $\mathrm{km}^{-2}$ ) generally increase with increasing runoff (Fig. 3a, $4 a-c)$, which is characteristic of a typical diffuse source where nitrate is carried along the flow pathways (Salmon et al., 2001; Kao et al., 2004). Fertilization from agricultural land uses superimposes the background nitrate from the forest (Table 3), and runoff controls the overall DIN export (Fig. 3c). Our upstream cases show that the agricultural 

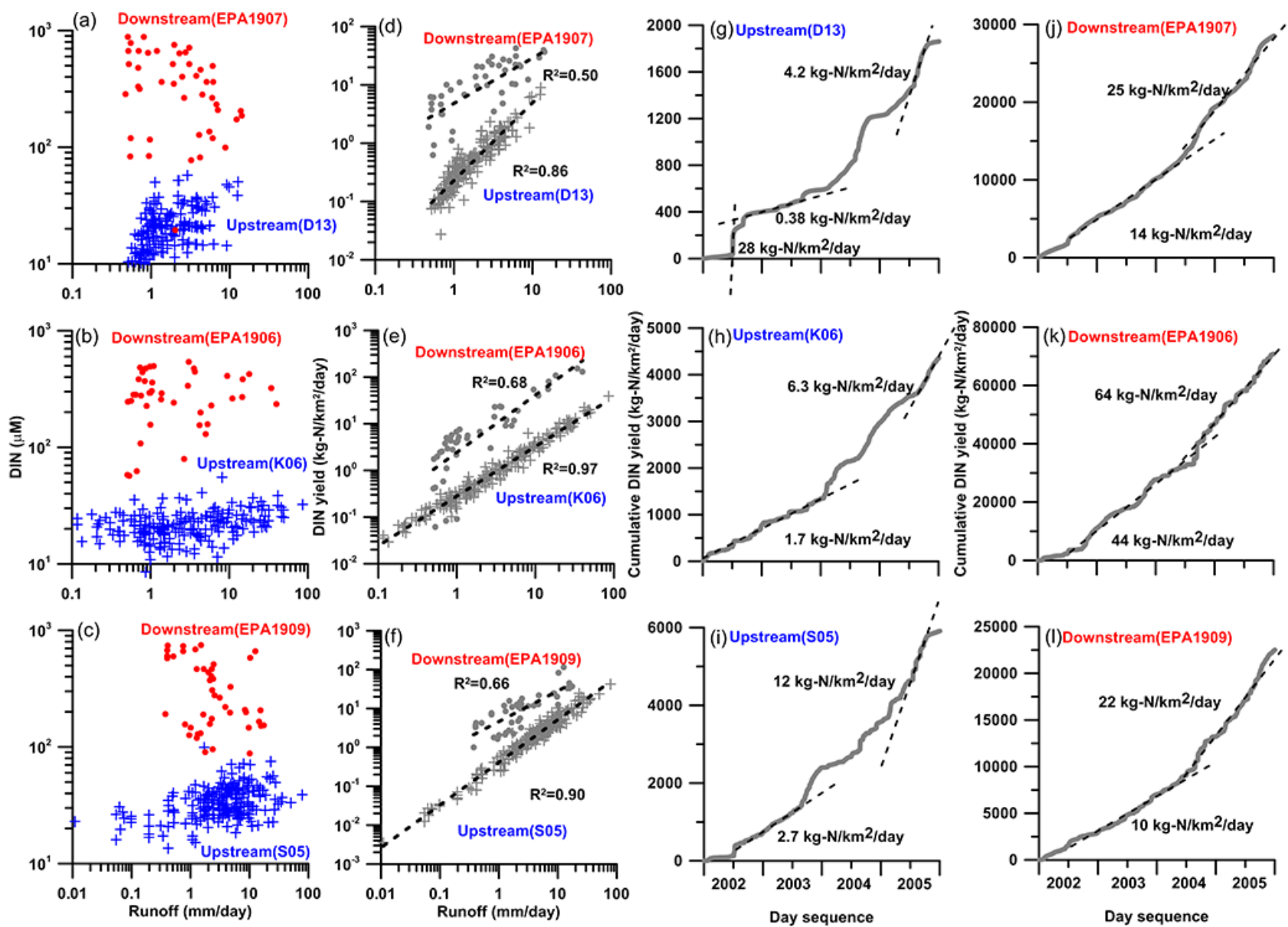

Figure 4. Scatter plots of DIN concentration (a, $\mathbf{b}, \mathbf{c})$ against runoff, daily DIN yield $(\mathbf{d}, \mathbf{e}, \mathbf{f})$ against runoff, and cumulative yields $(\mathbf{g}$ through l) of selected upstream and downstream sites. Dashed lines in $(\mathbf{d}, \mathbf{e}, \mathbf{f})$ are regression relations, while those in $(\mathbf{g}, \mathbf{h}, \mathbf{i}, \mathbf{j}, \mathbf{k}, \mathbf{l})$ are the mean yields of the window periods.

land use and runoff control the DIN concentration and yield (Fig. 5), which is consistent with previous studies on some less populated Mediterranean and Black Sea river basins $\left(<200 \mathrm{cap} \mathrm{km}^{-2}\right)$ with basin areas ranging from 68 $5526 \times 10^{3} \mathrm{~km}^{2}$. These previous studies also found that DIN yields are generally best correlated with $\mathrm{N}$ fertilizer application and runoff (Ludwig et al., 2010).

As for runoff, tropical cyclones are the main contributor to annual runoff in the entire West Pacific. In the neighbourhood watersheds of this study, four typhoons bringing $\sim 30-50 \%$ of the annual runoff could trigger $\sim 20-70 \%$ of the annual DIN export, dependent on the cultivation level within the watersheds (Lee et al., 2013). Our stepwise cumulative DIN yields for the upstream sites reveal the influence of typhoons on DIN export (Fig. 4g-1). For example, D13 shows an abrupt $\sim 28 \mathrm{~kg}-\mathrm{N} \mathrm{km}^{-2}$ day $^{-1}$ jump in cumulative DIN yield in mid-2002; this rate is $\sim 0.38 \mathrm{~kg}$ $\mathrm{N} \mathrm{km}^{-2}$ day $^{-1}$ during the dry year $(\sim 1400 \mathrm{~mm}$ in 2002 and 2003). Subsequently, the rate increases during the next wet year $(\sim 3100 \mathrm{~mm}$ in 2004 and 2005$)$ and remains at $\sim 4.2 \mathrm{~kg}$ -
$\mathrm{N} \mathrm{km}^{-2} \mathrm{day}^{-1}$ for most of the time in 2005. Two important relationships are addressed: (1) the abrupt jump and high DIN cumulative rate correspond well with typhoon events and runoff amount; and (2) the persistent high DIN yield in the wet year reveals sufficient nitrogen supply and/or storage to afford inexhaustible purging. Widespread anthropogenic $\mathrm{N}$ deposition (ANN) is one major source in $\mathrm{N}$ supply in Oceania (Kao et al., 2004). Atmospheric deposition (mainly from China, $\sim 2100$ to $\sim 3400 \mathrm{~kg}-\mathrm{N} \mathrm{km}^{-2} /$ year or $\sim 5.8$ to $\sim 9.3 \mathrm{~kg}-\mathrm{N} \mathrm{km}^{-2} \mathrm{day}^{-1}$ ) may explain the high DIN background in this region (Chen et al., 1998; Lin et al., 2000; Fang et al., 2008). Moreover, the DIN output only accounts for approximately half of the ANN input, which may indicate that $\mathrm{N}$ storage in the watershed is accumulating. The estimate of the total $\mathrm{N}$ pool in soil at $\mathrm{S} 12$ (Owen et al., 2010) is $690900 \mathrm{~kg}-\mathrm{N} \mathrm{km}^{-2}$, approximately $950 \times$ the export from the watershed (Table 4). This again supports our speculation of sufficient nitrogen supply/storage. In addition to the ANN, farmers usually over-use fertilizer to maintain crop 

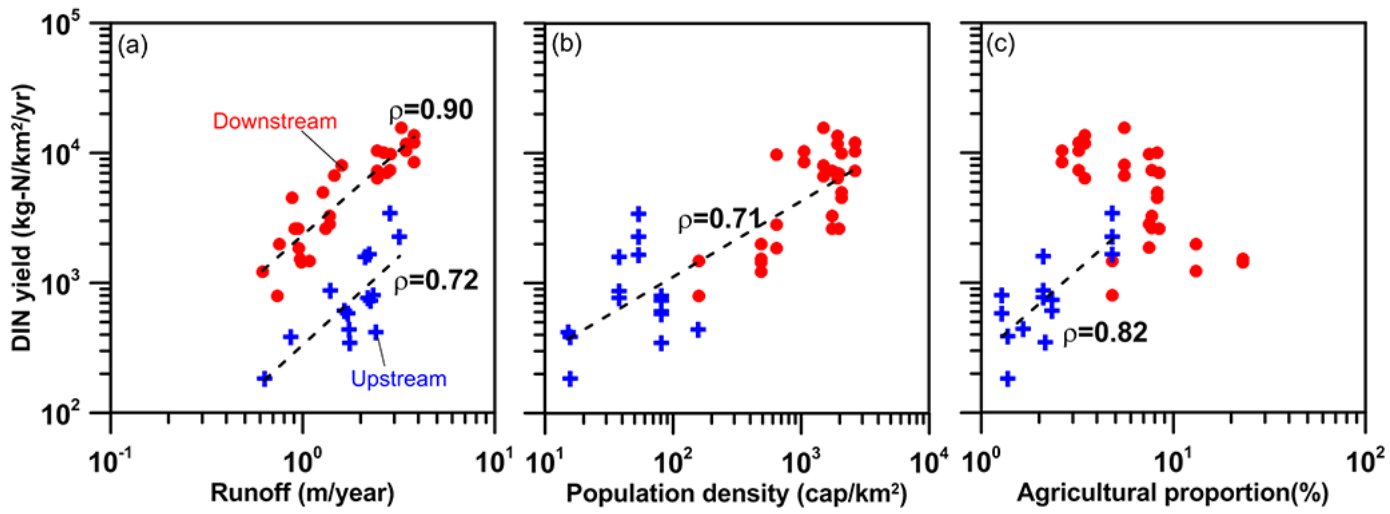

Figure 5. Annual DIN yields plotted against (a) runoff, (b) population density and (c) agricultural proportion at our sampling sites. Red circles and blue crosses represent downstream and upstream sites, respectively. The relationships are individually examined in terms of Pearson correlation coefficients $(\rho)$ for the upstream and downstream subsets and the data set as a whole. Fitted lines are drawn only if $\rho$ values are greater than 0.70 .

Table 5. Yield equations as a function of annual runoff and population density. Smith et al. (2005) generated different yield equations for different basin size groups.

\begin{tabular}{|c|c|c|c|c|c|c|c|}
\hline Table 5. Data source & $\begin{array}{r}\text { Basin } \\
\text { size }\left(\mathrm{km}^{2}\right)\end{array}$ & Intercept $\mathrm{t}^{\mathrm{a}}$ & $\begin{array}{r}\text { Runoff } \\
\text { coeff. }\end{array}$ & $\begin{array}{r}\text { Population } \\
\text { coeff. }\end{array}$ & $\begin{array}{l}\text { No. } \\
\text { data }\end{array}$ & $R^{2}$ & 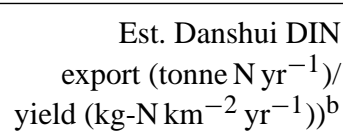 \\
\hline This study (whole data) & $6-2101$ & $3.64 \pm 0.23$ & $0.91 \pm 0.28$ & $0.53 \pm 0.09$ & 44 & 0.85 & $23435 / 8689$ \\
\hline Smith et al. (2003) & $10^{1}-10^{7}$ & 3.99 & 0.75 & 0.35 & 165 & 0.59 & $9156 / 3395$ \\
\hline \multirow{3}{*}{ Smith et al. (2005) } & $<10^{2}$ & $4.32 \pm 0.14$ & $0.82 \pm 0.23$ & $0.20 \pm 0.07$ & 62 & 0.19 & NA \\
\hline & $10^{2}-10^{3}$ & $4.09 \pm 0.09$ & $0.61 \pm 0.10$ & $0.38 \pm 0.06$ & 157 & 0.33 & NA \\
\hline & $10^{3}-10^{4}$ & $3.97 \pm 0.06$ & $0.64 \pm 0.08$ & $0.38 \pm 0.05$ & 155 & 0.39 & $10205 / 3783$ \\
\hline
\end{tabular}

a Yield equation: $\log \left(\mathrm{DIN}_{\mathrm{y}}\right)=$ Intercept + Runoff coefficient $\times \log (Q / 1000)+$ Population coefficient $\times \log ($ Pop $)$, DIN $_{\mathrm{y}}$ is DIN yield in $\left(\mathrm{mol} \mathrm{km}^{-2} \mathrm{yr}^{-1}\right), Q$ is annual runoff in $(\mathrm{mm})$, Pop is population density in $\left(\mathrm{cap} \mathrm{km}^{-2}\right)$; all the coefficients in the table are statistically significant, i.e. $p$-value $<0.01$. ${ }^{\mathrm{b}}$ Estimations were done at the given runoff of $2.5 \mathrm{~m}$ and population density of $2697 \mathrm{cap} \mathrm{km}^{-2}$.

production and compensate for fertilizer removed by heavy typhoon rainfall in the summer when crops are growing.

In the urbanized area downstream, built-in sewer systems are common, and sewage is usually categorized as a point source. Given that the DIN concentration/flux is relatively constant from a point source, higher runoff, on the contrary, dilutes the riverine DIN concentration (Figs. 3b, 4ac), unlike the behaviour observed in the upstream. Constant DIN yield rate is conventionally regarded as point source behaviour (Fig. $4 \mathrm{j}-1$ ). However, the rate changes from dry to wet year among the downstream sites, implying that the influence of non-point sources cannot be ruled out. In our study, the DIN point sources likely originate primarily from two sources: waste water treatment plants (WWTP) and rain water pumping stations (RWPS). The DIN flux from WWTP is presumed constant at $\sim 1718 \mu \mathrm{M}(\sim 100 \%$ ammonium $)$, with a treatment capacity of $5 \times 10^{5} \mathrm{~m}^{3}$ day $^{-1}$ (Wen et al., 2008). The water coming from upstream during high flow carries relatively lower DIN concentrations, which may dilute the DIN concentration in the downstream. Nevertheless, the WWTP can only account for $<1 \%$ of daily runoff (the average discharge of the Danshui River is $\sim 200 \mathrm{~m}^{3} \mathrm{~s}^{-1}$ ). In addition, the DIN in the effluents contributes $<1 \%$ of the riverine export, indicating that WWTP is not responsible for the downstream DIN. Further investigations, e.g. the measurement of nitrogen isotopes $\left(\delta^{15} \mathrm{~N}\right)$, could be implemented to identify the sources of DIN (Ohte et al., 2010). On the other hand, RWPS was designed to pump out the urban runoff collected by the drainage system within the protecting embankment. The outflow from RWPS depends on the magnitude of rainfall events and is limited to the maximum total capacity of the pumps. Meanwhile, the DIN concentration from RWPS may vary dissimilarly according to the surface runoff pathways, e.g. streets, playgrounds and parks. The urban runoff from roofs with different materials and streets with different traffic intensities, for example, show wide ranges of ammonium and nitrate concentrations from $\sim 5-344 \mu \mathrm{M}$ and $\sim 2-258 \mu \mathrm{M}$, respectively (Gobel et al., 2007). The service rate of public sanitary sewage in Taipei City is $<75 \%$. RWPS pumps not only handled urban 

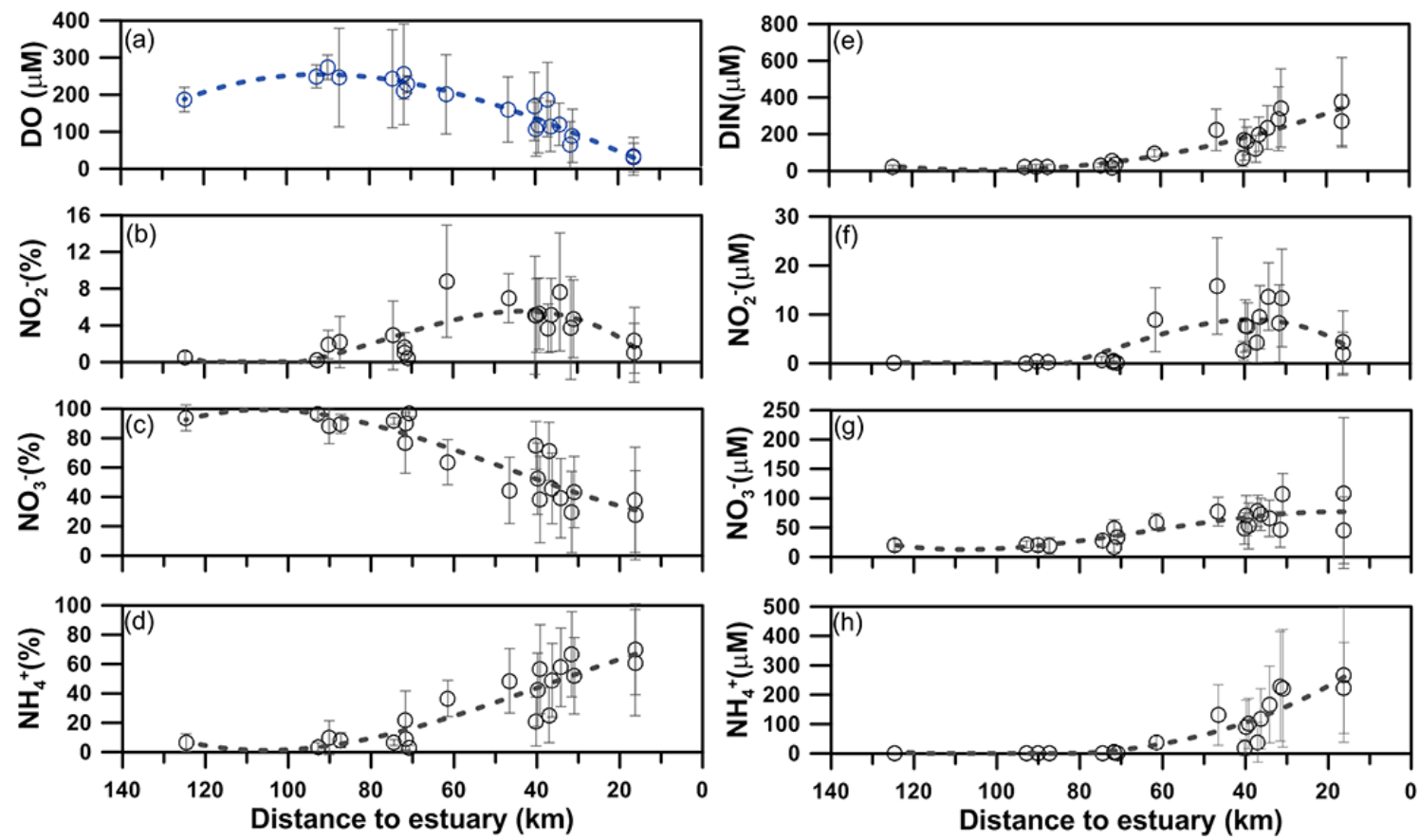

Figure 6. Longitudinal distributions of (a) dissolved oxygen, relative proportions of three DIN species, i.e. (b) nitrite, (c) nitrate and (d) ammonium, and concentrations of (e) DIN, (f) nitrite, (g) nitrate, and (h) ammonium along the Danshui River. Circles represent the mean of observations and bars are standard deviations. Dashed lines are polynomial fitting lines interpolating the trend along the river.

runoff but also untreated sewage. We therefore suggest that urban runoff is also an important source of DIN to the Danshui River. The estimation of the contribution of RWPS is beyond our scope and requires further investigation. Nevertheless, the constant export at downstream sites implies that the drainage system somehow integrates and modulates different DIN sources from its service area, smoothing the typhoontriggered DIN peaks in Fig. $4 \mathrm{j}-1$. Meanwhile, the rates of DIN yield have simultaneously increased $\sim 2 \times$ since mid2004, the onset of the wet years. This indicates that the DIN supply is sufficient to support such a $\sim 2 \times$ export because dense population guarantees abundant supply (Fig. 5b). The DIN in the downstream is a combination of point and diffuse sources, indicating that both of these are important for the downstream DIN. Although the controlling factors responsible for upstream and downstream DIN export are different, our observations suggest that the watersheds are transport dominated rather than supply limited. In addition, our observed DIN export and preliminary understanding of controlling factors can help advance nitrogen modelling work, e.g. NANI, SPRROW, and NEWS.

\subsection{Implications of DIN yields in the Danshui River}

We further use a logarithmic linear regression model to estimate the DIN export of our 20 sites in 2002-2005. As in the global model (Smith et al., 2003, 2005), the application of annual runoff and population density in this model produces the best estimates. Table 5 shows the equations derived from this study and those from the literature. The intercepts and coefficients of the equations shown in Table 5 are all statistically significant, i.e. $p$-value $<0.01$. Using our entire data set to determine the model coefficients, we obtain the following equation: $\log$ (DIN yield $)=3.64+0.91 \times \log ($ runoff $)+0.53 \times \log ($ population density). The coefficient for the $\log$ (runoff), $0.91 \pm 0.28$ (95\% confidence interval), is $\sim 20-50 \%$ larger than those in the previous work of Smith. In addition, the coefficient for $\log$ (population density), $0.53 \pm 0.09$, is $>40 \%$ larger. The large differences in the coefficients reveal the regional characteristics.

Figure 7 shows the relationships between DIN yields and runoff (Fig. 7a), population density (Fig. 7b) and agricultural proportion (Fig. 7c) of the Danshui River and other global rivers for comparison. Based on our equation in Table 5, at the long-term average runoff of $2.5 \mathrm{~m}$ and the current population density of $2697 \mathrm{cap} \mathrm{km}^{-2}$ for the Danshui River, DIN yield is estimated to be $\sim 6 \times 10^{5} \mathrm{~mol}-\mathrm{N} \mathrm{km}^{-2} \mathrm{yr}^{-1}$. This value is almost the highest on the global spectrum. High runoff and population density lead to the high DIN yield. Interestingly, the DIN production rate is much higher than the global model predicts based on the Danshui River runoff and population density. In terms of DIN flux, the Danshui River exports $\sim 23000$ ton- $\mathrm{N} \mathrm{yr}^{-1}$, which is $\sim 2.6 \times$ higher than that estimated by Smith et al. (2003) (Table 5). Considering the regional differences and watershed scale, Smith 


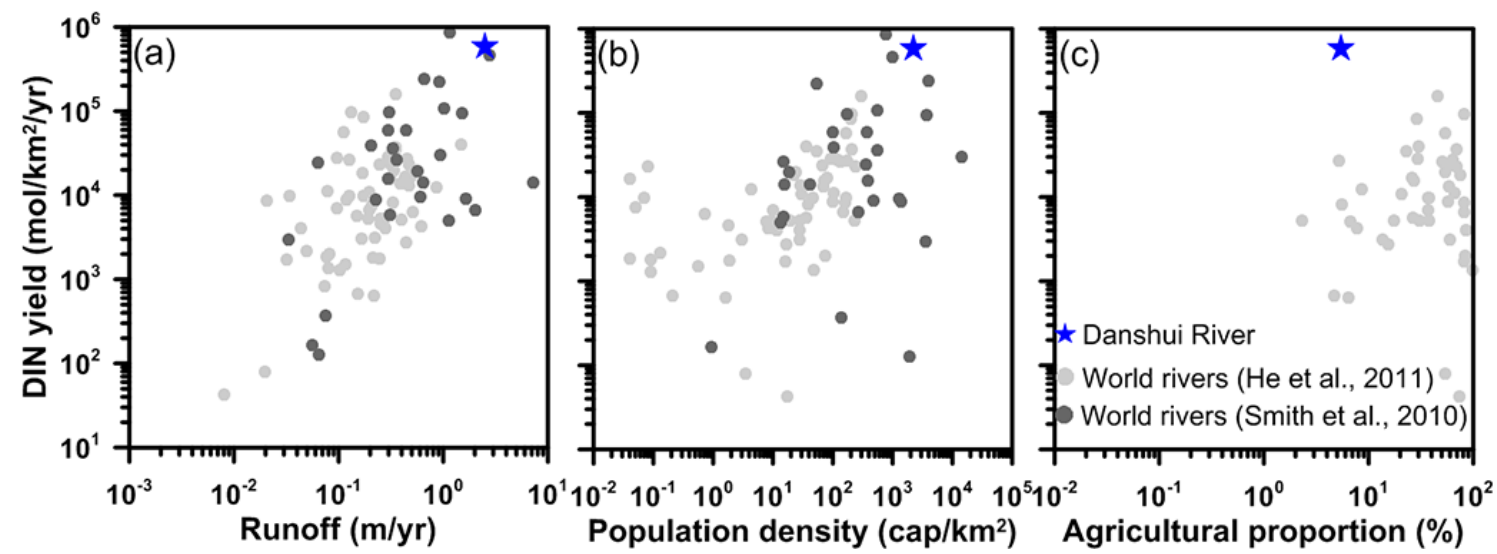

Figure 7. Scatter plots of DIN yields against (a) runoff, (b) population density, and (c) agricultural proportion. The export of the Danshui River (the star symbol) is plotted with global river data (grey circles). World river data are retrieved from He et al. (2011) and Smith et al. (2010).
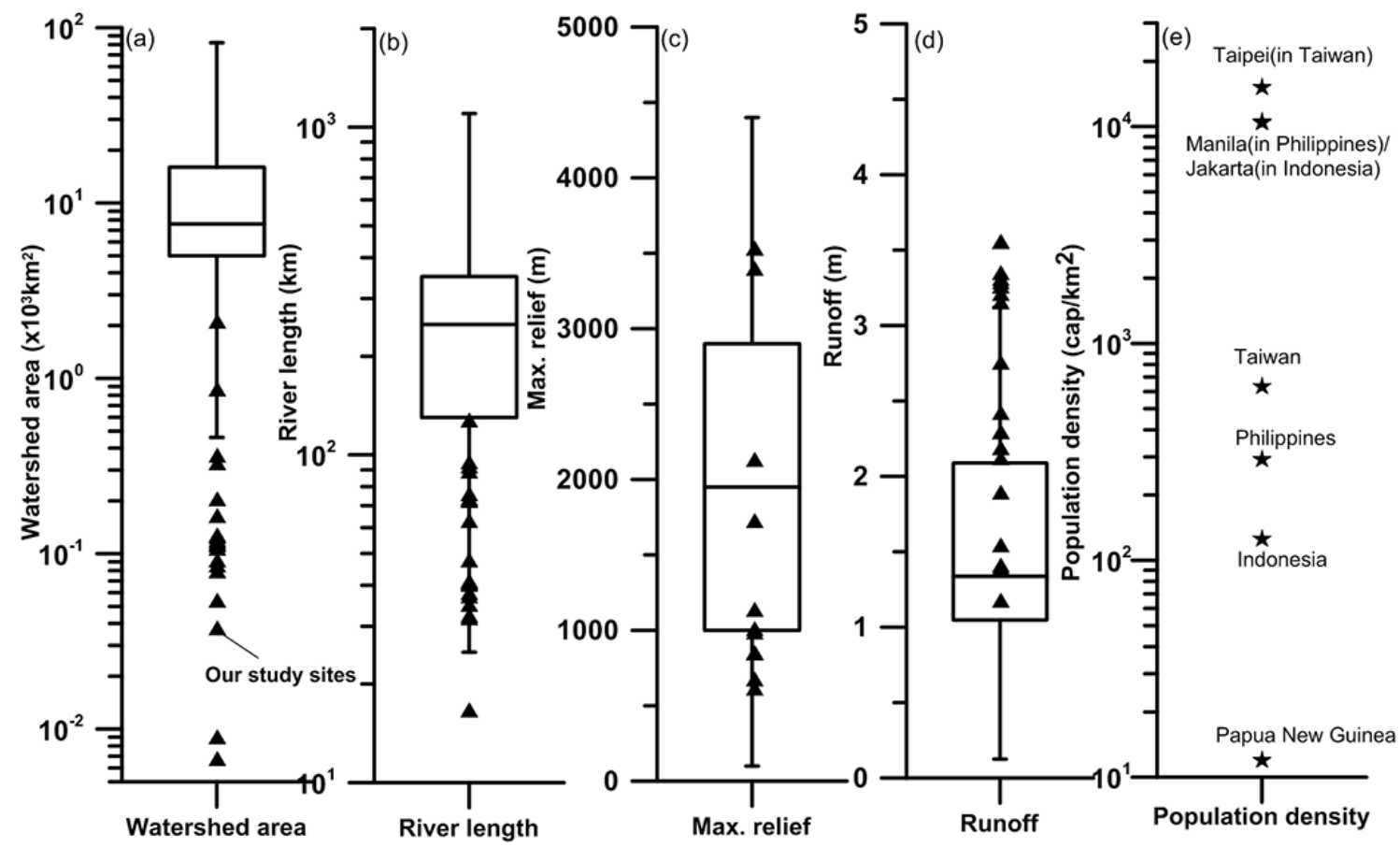

Figure 8. The spectra of characterized parameters, (a) watershed area, (b) river length, (c) maximum relief and (d) runoff, for Oceania rivers, and (e) population density in some Oceania countries and their cities (stars). The triangles represent our 20 sub-watersheds.

et al. (2005) updated their database and constructed watershed area-dependent equations to re-calculate global DIN export by compiling 496 rivers around the world. Nonetheless, our observation is still $\sim 2.3 \times$ higher than their updated DIN yield (Table 5). NEWS (Nutrient Export from Watersheds), another global model developed by Seitzinger et al. (2005), estimated an average DIN yield for Oceania

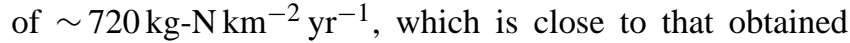
from relatively pristine upstream catchments in Taiwan (Kao et al., 2004; Lee et al., 2013 and this study); however, it is far lower than that predicted from the overall Danshui River $\left(8689 \mathrm{~kg}^{-\mathrm{N} \mathrm{km}} \mathrm{kg}^{-2} \mathrm{yr}^{-1}\right.$. Mayorga et al. (2010) further reduced the estimation to $\sim 250 \mathrm{~kg}-\mathrm{N} \mathrm{km}^{-2} \mathrm{yr}^{-1}$, demonstrating the need for regional observations. These cases highlight the fact that current global models very likely underestimate DIN export from the Oceania rivers. Here, we summarize some basic basin characteristics (watershed area, river length, maximum relief and population density) from 92 selected rivers that together drain $\sim 45 \%$ of Oceania (Fig. 8) (Milliman and Farnsworth, 2013). The Danshui 


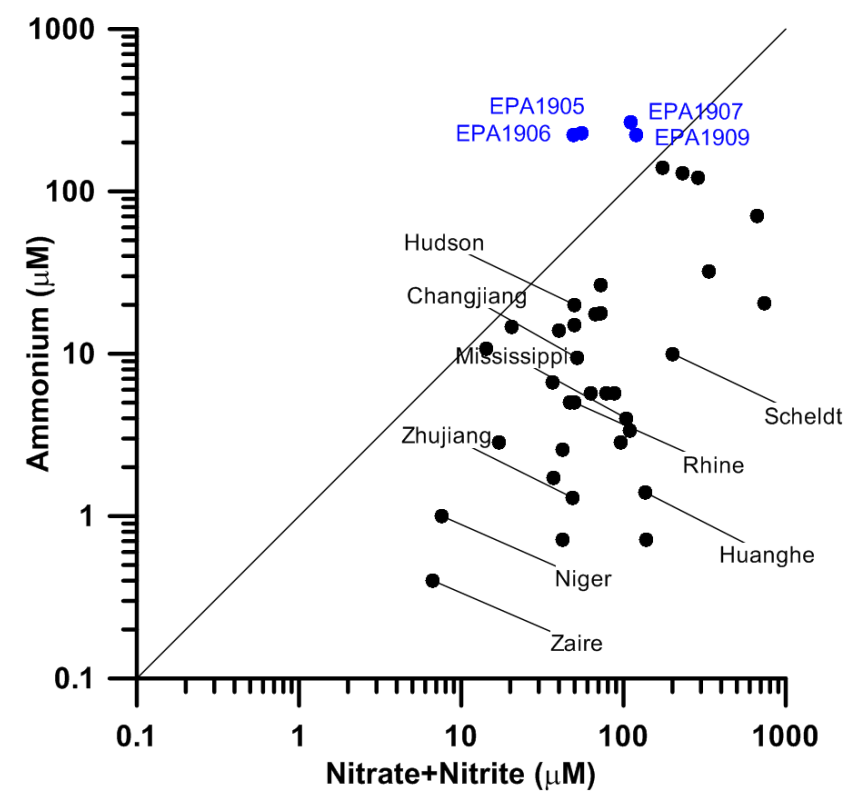

Figure 9. Ammonium concentration plotted against nitrate + nitrite concentration. The blue circles are the sites in/near the Danshui estuary, and the black circles are from documented large rivers. The $1: 1$ line is shown.

River shows the representativeness of rivers in high-standing Oceania islands, as all basins share similar environmental backgrounds. The watershed area of the Danshui River occupies $1.8 \times 10^{-3} \%$ of the Earth's land surface area, but discharges $\sim 90 \times 10^{-3} \%\left(\sim 23000\right.$ ton- $\left.\mathrm{N} \mathrm{yr}^{-1}\right)$ of the annual global DIN export to the ocean $(24.8 \mathrm{Tg} \mathrm{N}$, Seitzinger et al., 2005). This disproportionate DIN yield from small mountainous rivers underscores their importance in global nitrogen cycles and ecological footprints (Billen et al., 2010).

\subsection{Transformation among DIN species}

In this study, DIN speciation changes from the headwaters to the estuary (Fig. 6). Riverine nitrate is mainly influenced by soil leaching in the upstream. Year-round high temperature results in high rates of organic matter decomposition and nitrification. Moreover, excess rainfall induces farmers to apply much more ammonium sulfate and urea to facilitate crop growth. Ammonium in the leachate is quickly oxidized to nitrite and nitrate (Lee et al., 2013). In addition, based on the isotopic compositions of $\delta^{15} \mathrm{~N}$ and $\delta^{18} \mathrm{O}$ in nitrate, a previous study indicated that the denitrification process is insignificant in upstream mountainous watersheds and even in cultivated watersheds due to rapid infiltration (Peng et al., 2012). Previous studies also demonstrated that ammonium and nitrite concentrations in the headwater catchments of Taiwan are almost undetectable (Wen et al., 2008; Lee et al., 2013). Nitrate seems to flow into rivers as it is present in the soil water.

In the downstream, concentrated population and drainage systems facilitate the input of pollutants into the river. Recent research found that particulate organic matter in the downstream estuary consists primarily of phytoplankton consuming ammonium as the major nutrient source (Cheng, 2010; Liu et al., 2013). Eutrophication has resulted in hypoxia, the depletion of oxygen in the estuarine water column. By applying a mass-balanced trophic model, Ecopath with Ecosim, Lin et al. (2007) suggested that the estuary is a heterotrophic ecosystem. More organic matter is consumed than is produced in the estuary, leading to the depletion of dissolved oxygen and the release of ammonium (from the decomposition of organic matter) into the water. Low dissolved oxygen further impedes the oxidation of ammonium, resulting in ammonium being the dominant DIN species (Fig. 6).

We further collected DIN speciation data from some global rivers (Meybeck, 1982; Wollast, 1983; Bianchi et al., 1994; Duan et al., 2000; Goolsby and Battaglin, 2001; Zee et al., 2007) and plotted ammonium concentration against nitrate + nitrite concentration in Fig. 9. It is interesting to note that the Danshui River exports most of the DIN in the form of ammonium, unlike the large rivers that export nitrate as the predominant species. This export is a complex process involving the speciation and dynamics of nitrogen species associated with nitrification rate, denitrification rate, DO, organic matter decomposition, aeration in the air-water interface, and some physical parameters such as stream temperature and turbulence. (Hsiao et al., 2013; Bailey and Ahmadi, 2014). We speculate that the dominance of ammonium in the estuary of the Danshui River might be attributed to high flow velocity and short residence time. Many other instream processes affect DIN speciation during transportation along the stream; ammonium/nitrate assimilation and nitrate removal (denitrification/anammox) are involved. Oceania is surrounded by stratified oligotrophic water with limited bioavailable nutrients (Jiao et al., 2007; Martha and Kristen, 2012), again emphasizing the importance of DIN export from Oceania rivers in ecological footprints (Billen et al., 2010) and global nitrogen cycles.

\section{Conclusions}

Human activities enhance nitrogen export from land to ocean, altering global biogeochemical cycles. Oceania has been identified as a hotspot of global DIN export, although much less attention has been paid to the rivers of Oceania, where development is now rapid. This is a pioneer investigation on DIN speciation and distribution on basin-scale networks in the Oceania region with wide ranges of human alteration. The Danshui River holds the highest DIN yields among world rivers and could be a model for the rivers of Oceania. The positive correlation between runoff and DIN yield/flux reveals that hydrology exerts strong control over DIN export, i.e. DIN in our study area is transportdominated. The low yields in the upstream indicate that the forested watershed retains most of the DIN from atmospheric 
deposition ( $>2100 \mathrm{~kg}-\mathrm{N} \mathrm{km}^{-2} \mathrm{yr}^{-1}$ ), even though typhoons in the summer growing season flush more DIN out of the system. DIN export from low population density areas with agricultural activities should not be ignored given the common behaviour of over-fertilization. The much higher estimated regional DIN production rate compared to most global models highlights the disproportionate DIN yield from Oceania rivers. Unlike global large rivers where the DIN is dominated by nitrate, ammonium is the prevailing DIN species in the Danshui River. This perhaps results from the anaerobic conditions and short river water residence time that impede the removal of ammonium. Further investigation of instream processes is required to fully understand the rivers of Oceania. Our observational data supplement the global river database and serve as a scientific background for better understanding nutrient export from small mountainous watersheds and for promoting stream restoration and nutrient mitigation in Oceania rivers.

\section{The Supplement related to this article is available online at doi:10.5194/bg-11-5307-2014-supplement.}

Acknowledgements. This study is supported by the Taiwan National Science Council (101-2811-M-002-065, 102-2811-M002-071). We also thank Taiwan Power Company and Water Resources Agency for providing hydrological records.

Edited by: S. Bouillon

\section{References}

Bailey, R. T. and Ahmadi, M.: Spatial and temporal variability of in-stream water quality parameter influence on dissolved oxygen and nitrate within a regional stream network, Ecol. Model., 277, 87-96, 2014.

Bianchi, M., Bonia P., and Feliatra: Bacterial nitrification and denitrification rates in the Rhone River plume (northwestern Mediterranean Sea), Mar. Ecol. Prog. Ser., 102, 197-202, 1994.

Billen, G. and Garnier, J.: River basin nutrient delivery to the coastal sea: Assessing its potential to sustain new production of nonsiliceous algae, Mar. Chem., 106, 148-160, doi:10.1016.j.marchem.2006.1012.1017, 2007.

Billen, G., Beusen, A., Bouwman, L., and Garnier, J.: Anthropogenic nitrogen autotrophy and heterotrophy of the world's watersheds: Past, present, and future trends, Global Biogeochem. Cy., 24, GB0A11, doi:10.1029/2009GB003702, 2010.

Birgand, F., Faucheux, C., Gruau, G., Augeard, B., Moatar, F., and Bordenave, P.: Uncertainties in assessing annual nitrate load and concentration indicators, 1. Impact of sampling frequency and load estimation algorithms, Trans. ASABE, 53, 1-10, 2010.

Boesch, D. F.: Challenges and opportunities for science in reducing nutrient over-enrichment of coastal ecosystems, Estuaries, 25, 886-900, 2002.
Bouwman, A. F., Van Drecht, G., Knoop, J. M., Beusen, A. H. W., and Meinardi, C. R.: Exploring changes in river nitrogen export to the world's oceans, Global Biogeochem. Cy., 19, GB1002, doi:10.1029/2004GB002314, 2005.

Boyer, E. W., Howarth, R. W., Galloway, J. N., Dentener, F. J., Green, P. A., and Vorosmarty, C. J.: Riverine nitrogen export from the continents to the coasts, Global Biogeochem. Cy., 20, GB1S91, doi:10.1029/2005GB002537, 2006.

Chen, Z. S., Liu, J. C., and Cheng, C. Y.: Acid deposition effects on the dynamic of heavy metals in soils and their biological accumulation in the crops and vegetables in Taiwan, in: Acid Deposition and Ecosystem Sensitivity in East Asia, edited by: Bashkin V. and Park S. U., Nova Science Publishers, Hauppauge, NY, 188225, 1998.

Cheng, J. S.: A Study of Particulate Organic Carbon and Nitrogen and Dissolved Inorganic Nitrogen and Their Isotopic compositions in the Danshuei Estuary, Institute of Hydrological and Oceanic Sciences, National Central University, 2010.

Conley, D. J., Paer, H. W., Howarth, R. W., Boesch, D. F., Seitzinger, S. P., Havens, K. E., Lancelot, C., and Likens, G. E.: Controlling eutrophication: nitrogen and phosphorus, Science, 323, 1014-1015, 2009.

Diaz, R. J. and Rosenberg, R.: Spreading dead zones and consequences for marine ecosystems, Science, 321, 926-929, 2008.

Duan, S. W., Zhang, S., and Huang, H. Y.: Transport of dissolved inorganic nitrogen from the major rivers to estuaries in China, Nutr. Cycl. Agroecosys., 57, 13-22, 2000.

Duan, S. W., Xu, F., and Wang, L. J.: Long-term changes in nutrient concentrations of the Changjiang River and principal tributaries, Biogeochemistry, 85, 215-234, 2007.

Dumont, E., Harrison, J. A., Kroeze, C., Bakker, E. J., and Seitzinger, S. P.: Global distribution and sources of DIN export to the coastal zone: Results from a spatially explicit, global model, Global Biogeochem. Cy., 19, GB4S02, doi:10.1029/2005GB002488, 2005.

Fang, Y. T., Gundersen, P., Mo, J. M., and Zhu, W. X.: Input and output of dissolved organic and inorganic nitrogen in subtropical forests of South China under high air pollution, Biogeosciences, 5, 339-352, doi:10.5194/bg-5-339-2008, 2008.

Ferguson, R. I.: Accuracy and precision of methods for estimating river loads. Earth Surf. Proc. Land., 12, 95-104, 1987.

Galloway, J. N. and Cowling, E. B.: Reactive nitrogen and the world: 200 years of change, Ambio, 31, 64-71, 2002.

Galloway, J. N., Dentener, F. J., Capone, D. G., Boyer, E. W., Howarth, R. W., Seitzinger, S. P., Asner, G. P., Cleveland, C. C., Green, P. A., Holland, E. A., Karl, D. M., Michaels, A. F., Porter, J. H., Townsend, A. R., and Vorosmarty, C. J.: Nitrogen cycles: past, present, and future, Biogeochemistry, 70, 153-226, 2004.

Gobel, P., Dierkes, C., and Coldewey, W. G.: Storm water runoff concentration matrix for urban areas, J. Contam. Hydrol., 91, 2642, 2007.

Goolsby, D. A. and Battaglin, W. A.: Long-term changes in concentrations and flux of nitrogen in the Mississippi River Basin, USA, Hydrol. Process., 15, 1209-1226, 2001.

He, B., Kanae S., Oki, T., Hirabayashi, Y., Yamashiki, Y., and Takara, K.: Assessment of global nitrogen pollution in rivers using an integrated biogeochemical modeling framework, Water Res., 45, 2573-2586, 2011. 
Howarth, R. W., Billen, G., Swaney, D., Townsend, A., Jaworski, N., Lajtha, K., Downing, J. A., Elmgren, R., Caraco, N., Jordan, T., Berendse, F., Freney, J., Kudeyarov, V., Murdoch, P., and Liang, Z. Z.: Regional nitrogen budgets and riverine $\mathrm{N}$ and $\mathrm{P}$ fluxes for the drainages to the North Atlantic Ocean: Natural and human influences, Biogeochemistry, 35, 75-139, 1996.

Hsiao, S. S. Y., Hsu, T. C., Liu, J. W., Xie, X., Zhang, Y., Lin, J., Wang, H., Yang, J. Y. T., Hsu, S. C., Dai, M., and Kao, S. J.: Nitrification and its oxygen consumption along the turbid Chang Jiang River plume, Biogeosciences, 11, 2083-2098, doi:10.5194/bg-11-2083-2014, 2013.

Huang, J. C., Lin, C. C., Chan, S. C., Lee, T. Y., Hsu, S. C., Lee, C. T., and Lin, J. C.: Stream discharge characteristics through urbanization gradient in Danshui River, Taiwan :perspectives from observation and simulation, Environ. Monit. Assess., 184, 56895703, 2012a.

Huang, J. C., Lee, T. Y., Kao, S. J., Hsu, S. C., Lin, H. J., and Peng, T. R.: Land use effect and hydrological control on nitrate yield in subtropical mountainous watershed. Hydrol. Earth Sys. Sc., 16, 699-714, 2012b.

Jiao, N. Z., Zhang, Y., Zeng, Y. H., Hong, N., Chen, F., Liu R. L., and Wang, P. X.: Distinct distribution pattern of abundance and diversity of aerobic anoxygenic phototrophic bacteria in the global ocean, Environ. Microbiol., 9, 3091-3099, 2007.

Jickells, T. D.: Nutrient biogeochemistry of the coastal zone, Science, 281, 217-222, 1998.

Kao, S. J. and Liu, K. K: Stable carbon and nitrogen isotope systematics in a human-disturbed watershed (Lanyang-Hsi) in Taiwan and the export of biogenic particulate matter, Global Biogeochem. Cy., 14, 189-198, 2000.

Kao, S. J. and Liu, K. K: Exacerbation of erosion induced by human perturbation in a typical Oceania watershed: Insight from 45 years of hydrological records from the Lanyang-Hsi River, northeastern Taiwan, Global Biogeochem. Cy., 16, 1016, doi:10.1029/2000GB001334, 2002.

Kao, S. J. and Milliman, J. D.: Water and sediment discharge from small mountainous rivers, Taiwan: The roles of lithology, episodic events, and human activities, J. Geol., 116, 431-448, 2008.

Kao, S. J., Shiah, F. K., and Owen, J. S.: Export of dissolved inorganic nitrogen in a partially cultivated subtropical mountainous watershed in Taiwan, Water Air Soil. Poll., 156, 211-228, 2004.

Kao, S. J., Lee, T. Y., and Milliman, J. D.: Calculating highly fluctuated suspended sediment fluxes from mountainous rivers in Taiwan, Terr. Atmos. Ocean. Sci., 16, 653-675, 2005.

Lee, T. Y., Huang, J. C., Kao, S. J., and Tung, C. P.: Temporal variation of nitrate and phosphate transport in headwater catchments: the hydrological controls and land use alteration, Biogeosciences, 10, 2617-2632, doi:10.5194/bg-10-2617-2013,2013.

Lin, H. J., Shao, K. T., Jan, R. Q., Hsieh, H. L., Chen, C. P., Hsieh, L. Y., and Hsiao, Y. T.: A trophic model for the Danshuei River Estuary, a hypoxic estuary in northern Taiwan, Mar. Pollut. Bull., 54, 1789-1800, 2007.

Lin, T. C., Hamburg, S. P., King, H. B., and Hsia, Y. J.: Throughfall patterns in a subtropical rain forest of northeastern Taiwan, J. Environ. Qual., 29, 1186-1193, 2000.

Liu, K. K., Kao, S. J., Chiang, K. P., Gong, G.C., Chang, J., Cheng, J. C., and Lan, C. Y.: Concentration dependent nitrogen isotope fractionation during ammonium uptake by phytoplankton under an algal bloom condition in the Danshuei estuary, northern Taiwan, Mar. Chem. 157, 242-252, doi:10.1016/j.marchem.2013.10.005, 2013.

Ludwig, W., Bouwman, A. F., Dumont, E., and Lespinas, F.: Water and nutrient fluxes from major Mediterranean and Black Sea rivers: Past and future trends and their implications for the basinscale budgets, Global Biogeochem. Cy., 24, GB0A13, doi:10.1029/2009GB003594, 2010.

Martha, G. and Kristen, N. B., The organic complexation of iron in the marine environment: areview, Front. Microbiol., 28, 69, doi:10.3389/fmicb.2012.00069, 2012.

Mayorga, E., Seitzinger, S. P., Harrison, J. A., Dumont, E., Beusen, A. H. W., Bouwman, A. F., Fekete, B. M., Kroeze, C., and Van Drecht, G.: Global Nutrient Export from WaterSheds 2 (NEWS 2): Model development and implementation, Environ. Modell. Softw., 25, 837-853, doi:10.1016/j.envsoft.2010.01.007, 2010.

Meybeck, M.: Carbon, nitrogen, and phosphorus transport by world rivers, Am. J. Sci., 282, 401-450, 1982.

Milliman, J. D. and Syvitski, J. P. M.: Geomorphic/tectonic control of sediment discharge to the ocean: the importance of small mountainous rivers, J. Geol., 100, 525-544, 1992.

Milliman, J. D. and Farnsworth, K. L.: River Discharge to the Coastal Ocean: A Global Synthesis, Cambridge University Press, 2013.

Milliman, J. D., Farnsworth, K. L., and Albertin, C. S.: Flux and fate of fluvial sediments leaving large islands in the East Indies, J. Sea. Res., 41, 97-107, 1999.

Moatar, F. and Meybeck, M.: Compared performances of different algorithms for estimating annual nutrient loads discharged by the eutrophic river Loire, Hydrol. Process., 19, 429-444, 2005.

Ohte, N., Tayasu, I., Kohzu, A., Yoshimizu, C., Osaka, K., Makabe, A., Koba, K., Yoshida, N., and Nagata, T.:Spatial distribution of nitrate sources of rivers in the Lake Biwa watershed, Japan: Controlling factors revealed by nitrogen and oxygen isotope values, Water Resour. Res., 46, W07505, doi:10.1029/2009WR007871, 2010.

Owen, J. S., King, H. B.,Wang, M. K., and Sun, H. L.: Net nitrogen mineralization and nitrification rates in forest soil in northeastern Taiwan, J. Soil Sci. Plant Nut., 56, 177-185, 2010.

Peng, T. R., Lin, H. J., Wang, C. H., Liu, T. S., and Kao, S. J.: Pollution and variation of stream nitrate in a protected high-mountain watershed of Central Taiwan: evidence from nitrate concentration and nitrogen and oxygen isotope compositions, Environ. Monit. Assess., 184, 4985-4998, 2012.

Preston, S. D., Bierman, J. V. J., and Silliman, S. E.: An evaluation of methods for the estimation of tributary mass loads, Water Resour. Res., 25, 1379-1389, 1988.

Rabalais, N. N., Wiseman, W. J., Turner, R. E., SenGupta, B. K., and Dortch, Q.: Nutrient changes in the Mississippi River and system responses on the adjacent continental shelf, Estuaries, 19, 386-407, 1996.

Salmon, C. D., Walter, M. T., Hedin, L. O., and Brown, M. G.: Hydrolgoical controls on chemical export from an undisturbed oldgrowth Chilean forest, J. Hydrol., 253, 69-80, 2001.

Seitzinger, S. P., Kroeze, C., Bouwman, A. F., Caraco, N., Dentener, F., and Styles, R. V.: Global patterns of dissolved inorganic and particulate nitrogen inputs to coastal systems: Recent conditions and future projections, Estuaries, 25, 640-655, 2002. 
Seitzinger, S. P., Harrison, J. A., Dumont, E., Beusen, A. H. W., and Bouwman, A. F.: Sources and delivery of carbon, nitrogen, and phosphorus to the coastal zone: An overview of Global Nutrient Export from Watersheds (NEWS) models and their application, Global Biogeochem. Cy., GB4S01, doi:10.1029/2005GB002606, 2005.

Seitzinger, S. P., Mayorga, E., Bouwman, A. F., Kroeze, C., Beusen, A. H. W., Billen, G., Van Drecht, G., Dumont, E., Fekete, B. M., Garnier, J., and Harrison, J. A.: Global river nutrient export: A scenario analysis of past and future trends, Global Biogeochem. Cy., 24, GB0A08, doi:10.1029/2009GB003587, 2010.

Smith, S. V., Swaney, D. P., Talaue-McManus, L., Bartley, J. D., Sandhei, P. T., McLaughlin, C. J., Dupra, V. C., Crossland, C. J., Buddemeier, R. W., Maxwell, B. A., and Wulff, F.: Humans, hydrology, and the distribution of inorganic nutrient loading to the ocean, Bioscience, 53, 235-245, 2003.

Smith, S. V., Swaney, D. P., Buddemeier, R. W., Scarsbrook, M. R., Weatherhead, M. A., Humborg, C., Eriksson, H., and Hannerz, F.: River nutrient loads and catchment sizes, Biogeochemistry, 75, 83-107, 2005.

Smith, S. V., Swaney, D. P., and Talaue-McManus, L.: Carbon and Nutrient Fluxes in Continental Margins, chapter 14, edited by: Liu, K. K., Atkinson, L., Quinones, R., and Talaue-McManus, L., Springer, 2010.
Tu, J. Y., and Chou, C.: Changes in precipitation frequency and intensity in the vicinity of Taiwan: typhoon versus non-typhoon events, Environ. Res. Lett., 8, 014023, doi:10.1088/17489326/8/1/014023, 2013.

Turner, R. E., Rabalais, N. N., Justic, D., and Dortch, Q.: Global patterns of dissolved N, P and Si in large rivers, Biogeochemistry, 64, 297-317, 2003.

Webster, P. J., Holland, G. J., Curry, J. A., and Chang, H.-R.: Changes in tropical cyclone number, duration and intensity in a warm environment, Science, 309, 1844-6, 2005.

Wen, L. S., Jiann, K. T., and Liu, K. K.: Seasonal variation and flux of dissolved nutrients in the Danshuei Estuary, Taiwan: A hypoxic subtropical mountain river, Estuarine, Coast. Shelf Sci., 78, 694-704, 2008.

Wollast, R.: Major Biogeochemical Cycles and their Interactions, chapter 14, edited by: Bolin, B. and Cook, R. B., Wiley, 1983.

Zee, C., Roevros, N., and Chou L.: Phosphorus speciation, transformation and retention in the Scheldt estuary (Belgium/The Netherlands) from the freshwater tidal limits to the North Sea, Mar. Chem., 106, 76-91, 2007. 